\title{
Любов ЛИСяк
}

доктор економічних наук, профресор, Університет митної справи та фрінансів,

Дніпро, Україна, L_Lubov@ua.fm

ORCID ID: 0000-0003-2948-7089

\section{Світлана КАЧУЛА}

доктор економічних наук, доцент, Дніпровський державний аграрно-економічний

університет, Дніпро, Україна, S.Kachula@ukr.net

ORCID ID: 0000-0003-2540-862X

\section{Аліна АБДІН}

аспірантка кафредри державних, місцевих та корпоративних фрінансів, Університет митної справи та фрінансів, Дніпро, Україна, abdin@ua.fm

ORCID ID: 0000-0001-8277-0241

\section{БЮДЖЕТНА ПОАІТИКА У СФЕРІ ВИДАТКІВ В КООРДИНАТАХ СОЦІААЬНОГО РОЗВИТКУ}

Вступ. Соціальний розвиток є важливим процесом функціонування суспільства та передбачає зміцнення людського потенціалу, забезпечення належного рівня добробуту населення. Важливою умовою прогресивного соціального розвитку виступає політика у сорері видатків державного та місцевих бюджетів. Видатки, як інструмент бюджетної політики, є джерелом забезпечення суспільних потреб, відтак справляють значний вплив на розвиток соціальної сфери. В умовах кризи, зумовленої безпрецедентними обмеженнями ділової активності, падінням ВВП, загострюються соціальні проблеми, що актуалізує дослідження теоретичних засад, практичних механізмів/процесів і пріоритетних напрямів підвищення результативності бюджетної політики у сфері бюджетних видатків соціального спрямування.

Мета - розкрити теоретичні та обгрунтувати практичні аспекти видатків бюджету як інструменту бюджетної політики соціального розвитку суспільства.

Результати. Розкрито теоретичні засади сутності видатків бюджету у контексті необхідності реалізації соціальної фрнкції держави. Встановлено, що на фрормування видатків бюджету впливають економічні, політичні, соціальні та інституційні чинники. Виокремлено пріоритетні напрями бюджетної політики у сфрері соціальних видатків бюджету в умовах фрінансово-економічної кризи, а також на середньо- та довгострокову перспективу. Акцентовано увагу на проблемних аспектах бюджетної політики у сфрері видатків бюджету на забезпечення системи охорони здоров'я в Україні.

Висновки. Запропоновано напрями підвищення результативності бюджетної політики у сорері видатків бюджету на соціальний розвиток. Зокрема - удосконалення системи планування видатків, впровадження щорічних обов'язкових оглядів бюджетних видатків і витрат та їх своєчасне оприлюднення, удосконалення інституційних засад

(ㄱ Любов Валентинівна Лисяк, Світлана Валентинівна Качула, Аліна Володимирівна Абдін, 2020 
партнерства у процесі реалізації соціальних програм/проєктів, зміцнення інституту громадського контролю за виконанням місцевих бюджетів, підвищення прозорості, доступності, зрозумілості для населення та своєчасності представлення звітності про стан виконання соціальних програм. Акцентовано увагу на необхідності реалізації практичних заходів щодо усунення/нейтралізації негативних чинників, що впливають на реалізацію ефективної бюджетної політики у сфері видатків.

Ключові слова: бюджет, видатки бюджету, бюджетна політика, соціальний розвиток, програмно-цільовий метод, громадський контроль.

Табл.: 3, бібл.: 20.

\section{Любовь ЛЫСЯк}

доктор экономических наук, профрессор, Университет таможенного дела и финансов, Днепр, Украина

\section{Светлана КАЧУЛА}

доктор экономических наук, доцент, Днепровский государственный аграрно-экономический университет, Днепр, Украина

\section{Алина АБДИН}

аспирантка кафедры государственных, местных и корпоративных фринансов, Университет таможенного дела и финансов, Днепр, Украина

\section{БЮДЖЕТНАЯ ПОАИТИКА В ОБААСТИ РАСХОДОВ В КООРДИНАТАХ СОЦНАИЬНОГО РАЗВИТИЯ}

Введение. Социальное развитие является важным процессом функционирования общества и предусматривает укрепление человеческого потенциала, обеспечения надлежащего уровня благосостояния населения. Важным условием прогрессивного социального развития выступает политика в сфере расходов государственного и местных бюджетов. Расходы, как инструмент бюджетной политики, являются источником обеспечения общественных потребностей, поэтому оказывают значительное влияние на развитие социальной сферы. В условиях кризиса, обусловленного беспрецедентными ограничениями деловой активности, падением ВВП, обостряются социальные проблемы, а это актуализирует исследование теоретических основ, практических механизмов/процессов и приоритетных направлений повышения результативности бюджетной политики в сфрере бюджетных расходов социальной направленности.

Цель - раскрыть теоретические и обосновать практические аспекты расходов бюджета как инструмента бюджетной политики социального развития общества.

Результаты. Раскрыты теоретические основы сущности расходов бюджета в контексте необходимости реализации социальной функции государства. Установлено, что на формирование расходов бюджета влияют экономические, политические, социальные и институциональные фракторы. Выделены приоритетные направления бюджетной политики в сфере социальных расходов бюджета в условиях финансовоэкономического кризиса, а также на средне- и долгосрочную перспективу. Акцентировано внимание на проблемных аспектах бюджетной политики в сфере расходов на обеспечение системы здравоохранения в Украине. 
Выводы. Предложены направления повышения результативности бюджетной политики в сфрере расходов бюджета на социальное развитие. В частности - совершенствование системы планирования расходов, внедрение ежегодных обязательных осмотров бюджетных расходов и их своевременное обнародование, совершенствование институциональных основ партнерства в процессе реализации социальных программ/ проектов, укрепление института общественного контроля за исполнением местного бюджета, повышение прозрачности, доступности, понятности для населения и своевременности представления отчетности о выполнении социальных программ. Акцентировано внимание на необходимости реализации практических мер по устранению/нейтрализации фракторов, отрицательно влияющих на реализацию эфффективной бюджетной политики в сфере расходов.

Ключевые слова: бюджет, расходы бюджета, бюджетная политика, социальное развитие, программно-целевой метод, общественный контроль.

\section{Liubov LYSIAK}

Dr. Sc. (Economics), Prof., University of Customs and Finance, Dnipro, Ukraine, L_Lubov@ua.fm ORCID ID: 0000-0003-2948-7089

\section{Svitlana KACHULA}

Dr. Sc. (Economics), Assoc. Prof., Dnipro State University of Agriculture and Economics,

Dnipro, Ukraine, S.Kachula@ukr.net

ORCID ID: 0000-0003-2540-862X

\section{Alina ABDIN}

postgraduate student of the Department of State, Local and Corporate Finance,

University of Customs and Finance, Dnipro, Ukraine, abdin@ua.fm

ORCID ID: 0000-0001-8277-0241

\section{BUDGET POLICY IN THE FIELD OF EXPENDITURE IN THE COORDINATES OF SOCIAL DEVELOPMENT}

Introduction. Social development is an important process of society functioning and it involves human potential strengthening, ensuring the appropriate level of welfare. An important condition for progressive social development is the budget policy on state and local budget expenditures. Expenditures as an instrument of budget policy is a source of public needs, therefore significantly affect the social sphere development. In the context of the crisis caused by unprecedented restrictions on business activity, the fall of GDP exacerbates social problems; it actualizes the study of theoretical principles, practical mechanisms/processes and priority areas for improving the effectiveness of social spending field fiscal policy.

The purpose of the article is to reveal the theoretical aspects and substantiate the practical aspects of budget expenditures as a tool of budget policy of social development.

Results. Theoretical principles of the essence of budget expenditures in the context of necessity of the state social function implementation are revealed. It is established that the formation of budget expenditures is influenced by economic, political, social and institutional factors. The priority directions of budget policy in the field of social budget expenditures in the conditions of financial and economic crisis, as well as for the medium and long term are highlighted. Emphasis is placed on the problematic aspects of budget policy in the field of budget expenditures to ensure the health care system in Ukraine. 
Conclusions. The directions of increasing the efficiency of budgetary policy in the sphere of budget expenditures for social development are offered. In particular - improving the system of expenditure planning, introducing annual mandatory reviews of budget expenditures and their timely publication, improving the institutional framework of partnership in the social programs/projects implementation, strengthening the institution of public control over local budgets, increasing transparency, accessibility, clarity for population and the timeliness of reporting on the status of social programs implementation. Emphasis is placed on the need to implement practical measures to eliminate/neutralize negative factors that affect the implementation of effective budget policy of budget expenditures.

Keywords: budget, budget expenditures, budget policy, social development, program-target method, health care, review of budget expenditures, public control, partnership institute.

JEL Classification: E62, H51, H61, H72.

Постановка проблеми. Процеси глобалізації та євроінтеграційні прагнення України фрормують нові вимоги й умови для утвердження принципів соціальної держави та потребують здійснення економічного і соціального регулювання. У цьому аспекті вагомим $€$ використання інструментарію бюджетної політики, зокрема видатків бюджету. Вони мають спрямовуватися на потреби суспільного прогресу, реалізації соціальної функції держави, розвитку соціальної сфери, вирішення соціальних завдань і проблем. Підвищення ефективності видатків бюджету в умовах ринкової економіки значною мірою залежить від обґрунтованого поєднання всіх складових державної політики, зокрема узгодження фінансової та соціальної політики держави. Бюджетна політика за таких умов може мати визначальний вплив на стан соціального розвитку шляхом збалансування поточної та інвестиційної компонент бюджетних видатків, спрямування бюджетних видатків на реалізацію соціальних проектів і програм.

В умовах кризи, зумовленої безпрецедентними обмеженнями ділової активності, падінням ВВП загострюються соціальні проблеми, що актуалізує дослідження теоретичних засад, практичних механізмів/ процесів і пріоритетних напрямів підвищення результативності бюджетної політики у сфері видатків соціального спрямування.

Аналіз останніх досліджень і публікацій. Різним аспектам проблематики ефективності й оптимізації бюджетних видатків, підвищення ефективності бюджетної політики у сфері видатків бюджету для забезпечення соціального й економічного розвитку суспільства присвячено праці вітчизняних та іноземних вчених: Дж. Б'юкенена, Дж. Стігліца, В. Опаріна, О. Кириленко, І. Лютого, В. Макогон, І. Лук'яненко, Т. Набоки, Ю. Радіонова, І. Чугунова, В. Федосова, С. Юрія та інших.

На сьогодні питання ефективного використання видатків бюджету актуалізується необхідністю забезпечення життєздатності суспільства в умовах кризового фінансово-економічного стану глобальної та національних економік, введення карантинних обмежень, виникнення нових соціальних ризиків та лавиноподібним зростанням потреб у фрінансуванні соціальних напрямів/ потреб за рахунок державного та місцевих бюджетів, насамперед охорони здоров'я внаслідок масштабної небезпеки гострого перебігу пандемії COVID, посилення неви- 
значеності появи її нових хвиль і непередбачуваних наслідків.

Мета статті - обґрунтування теоретичних і практичних аспектів видатків бюджету як інструменту бюджетної політики соціального розвитку суспільства.

Виклад основного матеріалу дослідження. Необхідність розбудови докорінно нового механізму ведення господарства виникла в Україні із здобуттям незалежності, що передбачало також фрормування відповідної системи бюджетних відносин. В складний початковий період економічних перетворень в Україні наукові доробки вчених були присвячені розбудові державних фрінансів, зокрема колектив авторів під керівництвом В. Федосова, С. Огородника, В. Суторміної звертав першочергову увагу на видатки бюджету, і що особливо важливо - обґрунтовував необхідність посилення їх соціальної складової [1, с. 195]. Продовження дослідження державних фрінансів в умовах економічних перетворень підняло питання взаємозв'язку між доходами і видатками бюджету в аспекті їх пріоритетності при формуванні основних напрямів бюджетної політики, яке залишається відкритим для наукової дискусії. В. Опарін [2], Ю. Родіонов [3], Т. Набока [4] доводять першочерговість видатків бюджету, що ґрунтується ще на ідеях А. Сміта, А. Вагнера, розвинутих у працях відомих вчених-фрінансистів В. Лєбєдєва, А. Буковецького, І. Янжула, І. Озерова, в яких доходи бюджету розглядалися як підґрунтя для здійснення видатків.

Сучасний розвинений ринок, державне фінансове господарство, спираючись на теорії державних послуг і теорії податків, як ціни послуг, об'єктивно обумовлюють орієнтацію бюджетної політики у напрямку побудови бюджетних відносин і бюджету залежно від видатків, у яких втілюються суспільно необхідні потреби. Враховуючи, що видатки бюджету віддзеркалюють їх суспільне призначення, В. Опарін зазначає, що з позицій фінансової діяльності держави головним $є$ здійснення видатків у контексті реалізації функцій держави, а податки лише один із способів їх фрінансування [2, c. 40]. Формування системи видатків має здійснюватися на основі науково обґрунтованих розрахунків потреб у фрінансуванні, визначенні їх оптимальної структури. Важливим аспектом $€$ оцінка ефективності бюджетних видатків та сформована система контролю за їх здійсненням.

Відповідно до принципу загальності щодо прийнятих рішень у сфері суспільних фрінансів, бюджетні видатки, як справедливо вважають О. Кириленко і Б. Малиняк, мають бути спрямовані на здійснення тих програм і заходів, користь від яких отримають всі члени суспільства [5].

Видатки центрального бюджету держави або місцевих бюджетів в демократичному суспільстві мають бути засобом задоволення колективних потреб населення. Згідно з концепцією суспільного вибору суспільні інтереси мають бути гармонізовані з індивідуальними, у цьому процесі важливо знайти компроміс між суспільством і державою щодо рівня фрінансування соціальних благ. Саме держава покликана створювати умови для задоволення потреб громадян у суспільних благах, причому участь держави у цьому процесі визначається власне самими громадянами, вибір яких привів до перемоги певної політичної сили на виборах. В умовах демократії Ш. Бланкарт вважає важливим упорядкувати відносини у ссрері видатків бюджету, в іншому разі “різного роду маніпуляції з його видатковою частиною" призводять до ситуації, за якої “безрезультатним є прагнення реалізувати принцип справедливості щодо дохідної частини бюджету" [6, с. 206].

Видатки бюджету є об'єктивно необхідними, оскільки будь-яка фрункція держави 
може бути реалізована за умови ії фрінансування із бюджету, відповідно обсяг бюджету визначається передусім фрункціями держави. Таким чином, для дотримання видаткової концепції побудови бюджету першочерговим $€$ встановлення у країні оптимального (рівноважного) рівня податкового навантаження, при якому держава отримує достатню кількість доходів для здійснення корисних/необхідних суспільству державних видатків і платники податків погоджуються відносно безболісно для своїх інтересів віддати державі частину власних доходів (частину створеної доданої вартості).

Узагальнюючи різні підходи, можна зробити висновок, що бюджетні видатки соціального спрямування - це безперервне у часі цільове використання грошових ресурсів, акумульованих у державному та місцевих бюджетах на виконаня соціальної функції держави та органів місцевого самоврядування.

Оскільки бюджетна політика є одним із найвпливовіших елементів державної економічної та фрінансової політики, якість її формування та реалізації, визначення напрямів спрямування видатків бюджетів та ефективність їх здійснення на конкретні потреби галузей/секторів економіки, сфер діяльності, які $€$ пріоритетними на певному етапі, має безпосередній вплив на стан соціального розвитку суспільства. Бюджетна політика у сфері видатків має здійснюватися за умови науково обґрунтованого упорядкування функціональних обов'язків держави, консолідації суспільства, фрормування та збереження довіри до дій владних структур та у більш широкому контексті - становлення інституту культури та відповідальності у всіх сферах життєдіяльності суспільства (включаючи економіку та політику).

Позитивний вплив бюджетних видатків як інструменту бюджетної політики на темпи економічного зростання та соціального розвитку в цілому у державі та регіонах досягається як за рахунок необхідних обсягів бюджетних коштів, так і з дотриманням виваженої/оптимальної структури бюджетних видатків. У структурі видатків бюджету відображаються: пріоритетність бюджетної політики у межах акумульованих бюджетних коштів, можливості держави та органів місцевого самоврядування щодо фрінансування тих чи інших груп видатків, використовуючи кошти державного та місцевих бюджетів. Крім того, структура видатків зведеного бюджету свідчить про рівень соціально-економічного розвитку держави, певною мірою iï економічний та фінансовий потенціал, рівень фрінансових можливостей задовольняти суспільні потреби належної якості. Так, більше 50\% видатків зведеного бюджету України становлять соціальні видатки (на соціально-культурну сферу) (табл. 1).

Як свідчать дані табл. 1, упродовж 2014-2019 рр. найбільшими функціональними групами зведеного бюджету України $€$ видатки на соціальний захист та соціальне забезпечення, освіту, загальнодержавні функції. Частка видатків на соціальний захист та соціальне забезпечення населення у загальному їх обсязі за аналізований період становила у середньому 26,4\%, відповідний показник видатків на охорону здоров'я $-9,8 \%$, на освіту $-17,1 \%$, на духовний і фізичний розвиток - 2,3\%. У 2019 р., порівняно з 2014 р., відбулося зниження за всіма статтями видатків соціального спрямування: охорона здоров'я - на 1,2 відсоткових пунктів, духовний та фрізичний розвиток - 0,3 відсоткових пунктів, освіта - на 1,6 відсоткових пунктів, соціальний захист - на 2,8 відсоткових пунктів. Разом з цим, пріоритетним завданням бюджетної політики залишається забезпечення зростання рівня життя громадян та підвищення його якості в результаті сталого економічного розвитку. 
Структура видатків зведеного бюджету України в 2014-2019 рр., \%

\begin{tabular}{|c|c|c|c|c|c|c|c|c|}
\hline Функціональна класифікація & 2014 & 2015 & 2016 & 2017 & 2018 & 2019 & $\begin{array}{c}\text { Зміни } \\
\text { 2019/2014, } \\
\text { в.п. }\end{array}$ & $\begin{array}{c}\text { Середнє } \\
\text { знач. за } \\
\text { період }\end{array}$ \\
\hline Загальнодержавні фрункції & 14,7 & 17,3 & 16,1 & 15,7 & 15,3 & 14,8 & 0,2 & 15,7 \\
\hline Оборона & 5,2 & 7,7 & 7,1 & 7,0 & 7,8 & 7,8 & 2,6 & 7,1 \\
\hline $\begin{array}{l}\text { Громадський порядок, безпека та } \\
\text { судова влада }\end{array}$ & 8,6 & 8,1 & 8,6 & 8,4 & 9,4 & 10,5 & 2,0 & 8,9 \\
\hline Економічна діяльність & 8,3 & 8,3 & 7,9 & 9,8 & 11,3 & 11,2 & 2,2 & 9,5 \\
\hline $\begin{array}{l}\text { Охорона навколишнього природного } \\
\text { середовища }\end{array}$ & 0,7 & 0,8 & 0,8 & 0,7 & 0,7 & 0,7 & 0 & 0,7 \\
\hline Житлово-комунальне господарство & 3,4 & 2,3 & 2,1 & 2,6 & 2,4 & 2,5 & $-1,0$ & 2,5 \\
\hline Охорона здоров'я & 10,9 & 10,4 & 9,0 & 9,7 & 9,3 & 9,4 & $-1,2$ & 9,8 \\
\hline Духовний та фрізичний розвиток & 2,7 & 2,4 & 2,0 & 2,3 & 2,3 & 2,3 & $-0,3$ & 2,3 \\
\hline Освіта & 19,1 & 16,8 & 15,5 & 16,8 & 16,8 & 17,4 & $-1,6$ & 17,1 \\
\hline $\begin{array}{l}\text { Соціальний захист та соціальне } \\
\text { забезпечення }\end{array}$ & 26,4 & 25,9 & 30,9 & 27,0 & 24,7 & 23,4 & $-2,8$ & 26,4 \\
\hline
\end{tabular}

* Складено на основі [7; 8].

Слід зазначити, що обсяг видатків зведеного бюджету у ВВП поступово зростає. Так, на охорону здоров'я у 2019 р. такі видатки становили 3,2\% ВВП, у 2020 р. - заплановано 4\% ВВП (при цьому цей показник у 2020 р. змінювався внаслідок перерозподілу бюджетних коштів на рівні розпорядників, унаслідок необхідності фрінансової підтримки сфери охорони здоров'я в результаті COVID-19), а обсяг видатків зведеного бюджету на освіту в 2019 р. становив $6 \%$ ВВП, у 2020 р. - згідно з планом має бути на рівні 6,6\% ВВП.

Аналіз структури видатків соціального спрямування зведеного бюджету України за економічною класифікацією, зокрема співвідношення між поточними і капітальними видатками дає змогу зробити невтішні висновки щодо стабільного переважання поточних видатків над видатками розвитку (табл. 2).

Структура видатків зведеного бюджету залежить від специфіки тієї чи іншої галузі, водночас, загальною тенденцією $є$ переважання у соціальних видатках поточного споживання, що значно ускладнює успішне вирішення стратегічних завдань соціальної політики щодо розвитку людського потенціалу та задоволення потреб населення. Впродовж 2017-2018 рр. у структурі видатків на охорону здоров'я відбулося зниження частки видатків на використання товарів і послуг (з 79,9\% до 54,8\%), суттєво зросли інші поточні видатки (з 4,0\% до 31,9\%), частка капітальних видатків у 2019 р. (після зниження в 2018 р., порівняно з 2017 р., на 0,3\%) повернулась до рівня 2017 р. (9,0\%). У структурі видатків зросла їх частка на оплату праці і нарахування на заробітну плату, зокрема у видатках на духовний та фрізичний розвиток - з 37,3\% до $39,1 \%$, на освіту - з 54,8\% до 56,8\%. Водночас знизилися капітальні видатки з 7,8\% до 7,1\% (духовний та фрізичний розвиток) та з 15,5\% до $12,1 \%$ (освіта). У структурі поточних видатків на соціальний захист та соціальне забезпечення знизилася частка на соціальне забезпечення (з 94,0\% до 92,7\%). Слід зазначити, що окреслені зміни, незважаючи 
Структура видатків зведеного бюджету України соціального спрямування за економічною бюджетною класифрікацією, \%*

\begin{tabular}{|c|c|c|c|c|c|c|}
\hline \multirow{2}{*}{ Видатки } & \multicolumn{2}{|c|}{2017} & \multicolumn{2}{|c|}{2018} & \multicolumn{2}{|c|}{2019} \\
\hline & Поточні & Капітальні & Поточні & Капітальні & Поточні & Капітальні \\
\hline Охорона здоров'я & 91,0 & 9,0 & 91,3 & 8,7 & 91,0 & 9,0 \\
\hline $\begin{array}{l}\text { Оплата праці і нарахування } \\
\text { на заробітну плату }\end{array}$ & 7,1 & - & 4,3 & - & 4,3 & - \\
\hline Використання товарів і послуг & 79,9 & - & 77,2 & - & 54,8 & - \\
\hline Інші поточні видатки & 4,0 & - & 10,1 & - & 31,9 & - \\
\hline Духовний та фізичний розвиток & 84,5 & 15,5 & 85,8 & 14,2 & 87,9 & 12,1 \\
\hline $\begin{array}{l}\text { Оплата праці і нарахування } \\
\text { на заробітну плату }\end{array}$ & 37,3 & - & 37,0 & - & 39,1 & - \\
\hline Використання товарів і послуг & 20,0 & - & 22,4 & - & 22,7 & - \\
\hline Поточні трансферти & 24,7 & - & 24,4 & - & 24,4 & - \\
\hline Інші поточні видатки & 2,5 & - & 2,0 & - & 1,8 & - \\
\hline Освіта & 92,2 & 7,8 & 92,7 & 7,3 & 92,9 & 7,1 \\
\hline $\begin{array}{l}\text { Оплата праці і нарахування } \\
\text { на заробітну плату }\end{array}$ & 54,8 & - & 56,6 & - & 56,8 & - \\
\hline Використання товарів і послуг & 34,2 & - & 33,7 & - & 33,8 & - \\
\hline Інші поточні видатки & 3,3 & - & 2,3 & - & 2,0 & - \\
\hline $\begin{array}{l}\text { Соціальний захист та соціальне } \\
\text { забезпечення }\end{array}$ & 98,9 & 1,1 & 98,2 & 1,8 & 98,8 & 1,2 \\
\hline $\begin{array}{l}\text { Оплата праці і нарахування } \\
\text { на заробітну плату }\end{array}$ & 2,3 & - & 2,4 & - & 2,8 & - \\
\hline Використання товарів і послуг & 1,8 & - & 1,8 & - & 2,1 & - \\
\hline Соціальне забезпечення & 94,0 & - & 93,2 & - & 92,7 & - \\
\hline Інші поточні видатки & 1,7 & - & 2,6 & - & 2,5 & - \\
\hline
\end{tabular}

* Складено на основі [8].

на реалізацію важливих реформ у соціальній сфері, не відображають процеси оптимізації структури соціальних видатків.

Метою Стратегії сталого розвитку "Україна 2020", реалізація якої завершується, було впровадження в Україні європейських стандартів життя. Особлива увага в Стратегії приділялася безпеці життя та здоров'ю людини, розвитку ефективної медицини, захищеності соціально вразливих верств населення, формуванню безпечного стану довкілля і доступу до якісної питної води, безпечних харчових продуктів і про- мислових товарів; доступ до високоякісної освіти, системи охорони здоров'я та інших послуг в державному та приватному секторах [9]. Активне реформування соціальної сфрери, зокрема охорони здоров'я, пенсійна реформа, удосконалення управління публічними фінансами, бюджетна реформа, реформування місцевих фрінансів має на меті забезпечення фрінансової самодостатності місцевого самоврядування з метою створення комфортних умов для проживання громадян, надання їм високоякісних і доступних публічних послуг в Україні. 
Національні цілі сталого розвитку України базуються на сімнадцяти глобальних Цілях сталого розвитку та зокрема передбачають подолання бідності і скорочення нерівності (включаючи гендерну), забезпечення охорони громадського здоров'я, здорового способу життя, благополуччя, інклюзивної та справедливої якісної освіти і заохочення/сприяння можливостям навчатися впродовж усього життя для всіх. Цілі сталого розвитку України на період до 2030 р. мають бути орієнтирами для розроблення проектів прогнозних і програмних документів, проектів нормативно-правових актів з метою забезпечення збалансованості економічного, соціального та екологічного вимірів сталого розвитку України [10]. У 2020 р. в Україні репрезентовано Національну економічну стратегію 2030 (HEC), у якій серед важливих векторів розвитку визначено підвищення якості життя населення як запоруки соціальної стабільності та покращення продуктивності діяльності населення [11]. Це передбачає забезпечення розвитку кожного члена суспільства (культури та освіти), забезпечення умов для здорового життя (охорона здоров'я, соціальні послуги і молодіжний розвиток (підтримка вразливих груп населення і підтримка молоді), охорона довкілля.

Бюджетне програмування дає змогу активно використовувати цільові програми як інструмент бюджетної політики. Використання програмно-цільового методу у бюджетному процесі відображається у програмній класифрікації видатків бюджету. Видатки бюджету на реалізацію соціальних бюджетних програм спрямовуються на зниження рівня безробіття, підвищення якості людського капіталу, зокрема зміцнення здоров'я населення, підвищення якості освіти, гармонізацію соціального й економічного розвитку. У таких ключових сферах, як охорона здоров'я, освіта і пріоритетна інфрраструктура, за оцінками МВФ, країнам, що розвиваються (з низькими доходами) необхідно щорічно здійснювати значні додаткові витрати та довести їх в 2030 р. до половини трильйона доларів США, що становитиме майже 15\% їх сукупного ВВП [12].

Аналіз фрінансування програм, які реалізуються Міністерством охорони здоров'я України, свідчить про їх орієнтацію за визначеними урядом стратегічними пріоритетами: люди менше хворіють (ціль 1); люди, що захворіли, швидше одужують (ціль 2); люди довше живуть (ціль 3). Для досягнення цих цілей у 2020 р. реалізуються такі програми: “Громадське здоров'я та заходи боротьби з епідеміями”, “Доступні ліки”, “Медичні закупівлі України”, "Лікування громадян України за кордоном”, “Програма медичних гарантій”, “Поліпшення охорони здоров'я на службі у людей” та інші. На Програму медичних гарантій, яка охоплює первинну медичну допомогу, спеціалізовану амбулаторну та госпітальну допомогу, екстрену медичну допомогу, медичну реабілітацію та паліативну медичну допомогу в 2020 р. спрямовано 64\% від сукупних видатків на всю медичну галузь. Фінансування видатків соціального спрямування у розрізі бюджетних програм потребує вдосконалення. Це стосується порядку розробки бюджетних програм, формування мети і визначення показників результативності й еорективності, які відображатимуть більш достовірну і детальну оцінку їх виконання. Слід зазначити, незважаючи на те, що в Бюджетному кодексі України (ст. 28) передбачено оприлюднення відповідних звітів головними розпорядниками бюджетних коштів на власних веб-сайтах, інформація більшістю з них подається несвоєчасно, у незрозумілому для пересічного громадянина вигляді (відсутні огляди, аналітична оцінка, рішення, висновки тощо), крім того, пошук звітів займає багато часу. 
Залежно від пріоритетних напрямів бюджетної політики соціального спрямування наслідки їх фрормування і реалізації для суспільства $є$ значними. Так, забезпечення базового набору державних соціальних гарантій фрінансового забезпечення найбільш вразливих верств населення характеризують відносну статичність соціальних процесів, водночас реалізація програм розвитку освіти, науки, культури, охорони здоров'я, впровадження соціальних інновацій та здійснення інвестицій в розбудову соціальної інфраструктури характеризує процеси прогресивного соціального розвитку, зміцнення людського потенціалу та реалізації політики зайнятості, дотримання соціальної справедливості у суспільстві.

Через перманентне повторення економічних криз та загострення негативних тенденцій соціально-політичного характеру питання забезпечення оптимального рівня бюджетних видатків $є$ одним з найбільш пріоритетних. Випадки нецільового використання бюджетних коштів за умов значного дефіциту Державного бюджету України свідчать, що вагомим інструментом їх недопущення/усунення $€$ підвищення ефективності контролю за використанням бюджетних видатків. У цьому контексті важливим аспектом стає зрілість інституційного середовища, створення ефективних соціальних і фінансових інститутів, забезпечення соціальної безпеки.

Крім притаманних усьому періоду існування незалежної України проблем із забезпеченням ефективного використання коштів бюджетів, останніми роками посилилася дія негативних чинників, серед яких найбільш гострими є: соціально-політична та фрінансово-економічна кризи, втрата частини території, а отже, і надходжень до державного та місцевих бюджетів, що спричинило стрімке погіршення стану публічних фрінансів. Також суттєво зроста- ли видатки на оборону й обслуговування боргових зобов'язань, тоді як інші видатки зростали набагато меншими темпами. Складна фінансово-економічна ситуація в державі призвела до стрімкого зниження рівня життя громадян, збільшення кількості людей з інвалідністю, переселенців та інших категорій осіб, що потребують тих чи інших соціальних видатків/допомог/виплат. Пандемія COVID 19 та можливі сплески іiї нових хвиль загострила соціальні проблеми в Україні. Внаслідок карантинних обмежень відбулося падіння виробництва та збуту, зросла інфляція, знизився рівень зайнятості населення, якість і доступність суспільних благ у сфері охорони здоров'я, освіти та культури, зросло навантаження на державний та місцеві бюджети.

Протягом останніх років спостерігалися негативні тенденції, які, в тому числі, прямо вплинули на стан державних та місцевих фінансів, у результаті чого змінювалась і структура бюджетних видатків. Серед вагомих чинників, що впливають та у перспективі посилюватимуть свій вплив на структурні зміни видатків бюджету, ймовірніше, будуть демографічні. Багато європейських учених наполягають на реформуванні фрінансової та зокрема бюджетної політики в межах єврозони. На їхню думку, збереження старої європейської моделі розвитку неможливе, поряд із загостренням конкуренції на світових ринках, через прогресуюче старіння населення в Європі. За розрахунками Європейської комісії, тільки внаслідок цього у найближчі сорок років більшість країн ЄС будуть вимушені збільшити частку державних витрат у ВВП. Для компенсації такого навантаження необхідно змінити політику державних видатків.

Світова тенденція старіння населення характерна і для України, що спричинить зростання витрат на медицину, соціальні послуги, пенсійне забезпечення. Тим біль- 
ше, що низький рівень життя в Україні став причиною відтоку населення працездатного віку, так званих трудових мігрантів, за ії межі. Про масштаби цього явища свідчить факт, що приватні грошові перекази українських трудових мігрантів за кордоном у 2019 р. в 5 разів перевищували прямі іноземні інвестиції в країну.

Поглиблення процесів бюджетної децентралізації, яку проводять останніми роками, сприяло підвищенню ефективності виконання соціальної та інших фрункцій держави завдяки раціональному розподілу повноважень щодо надання суспільних благ і послуг між центральними органами влади та органами місцевого самоврядуванням. Матеріальною базою забезпечення можливості місцевого самоврядування виконувати власні та делеговані завдання виступають доходи місцевих бюджетів, а показником оцінки ефективності реформування місцевих фрінансів може слугувати динаміка видатків місцевих бюджетів на 1 особу/мешканця. Порівняння цього показника в Україні з іншими країнами Центральної Європи та Балтики, які вирішували та продовжують вирішувати проблеми постсоціалістичної трансформації та впровадження реформ, подано у табл. 3 .

Дані табл. 3 свідчать про позитивні наслідки впровадження реформи бюджетної децентралізації в Україні та реалізації бюджетної політики, адже за досліджуваний період видатки місцевих бюджетів України на 1 мешканця зросли на 72,8\%. Проте в абсолютному виразі, порівняно з окремими країнами $€ C$ та у середньому по $€ C$, показник залишається незначним, що закономірно з огляду на розмір ВВП України. Порівняно з європейськими країнами, ВВП в Україні впродовж тривалого періоду залишається низьким, що є вагомою проблемою державних і місцевих фрінансів. Так, номінальний ВВП на одну особу в Україні

Видатки місцевих бюджетів на 1 особу в країнах Європи, євро*

\begin{tabular}{|c|c|c|c|c|c|c|c|}
\hline \multirow{2}{*}{ Країна } & \multirow{2}{*}{2015} & \multirow{2}{*}{2016} & \multirow{2}{*}{2017} & \multirow{2}{*}{2018} & \multirow{2}{*}{2019} & \multicolumn{2}{|c|}{ Відхилення 2019 до 2015} \\
\hline & & & & & & євро & $\%$ \\
\hline Болгарія & 658 & 464 & 520 & 579 & 652 & -6 & $-0,86$ \\
\hline Польща & 1466 & 1450 & 1647 & 1868 & 2008 & 542 & 36,98 \\
\hline Румунія & 794 & 782 & 847 & 852 & 967 & 174 & 21,91 \\
\hline Словенія & 1655 & 1578 & 1676 & 1848 & 1938 & 283 & 17,09 \\
\hline Словаччина & 1092 & 990 & 1091 & 1179 & 1279 & 187 & 17,11 \\
\hline Хорватія & 1302 & 1322 & 1370 & 1569 & 1707 & 404 & 31,05 \\
\hline Чехія & 1836 & 1725 & 1964 & 2338 & 2498 & 662 & 36,08 \\
\hline Угорщина & 884 & 707 & 803 & 896 & 1008 & 124 & 13,99 \\
\hline Латвія & 1225 & 1280 & 1480 & 1738 & 1738 & 513 & 41,87 \\
\hline Литва & 1016 & 1049 & 1168 & 1309 & 1476 & 460 & 45,25 \\
\hline Естонія & 1473 & 1524 & 1745 & 1893 & 2140 & 667 & 45,27 \\
\hline$\epsilon C 28$ & 4599 & 4679 & 4790 & 4991 & 5156 & 557 & 12,12 \\
\hline Україна & 271 & 292 & 391 & 422 & 468 & 197 & 72,84 \\
\hline
\end{tabular}

* Складено на основі [7; 8; 13; 14]. 
у 2019 р. становив 3659 дол США [13], що в 1,8 рази менше, ніж в Білорусі, майже в 2,5 рази менше, ніж в Туреччині, в 4,3 рази менше, ніж в Польщі та в 5,3 рази - ніж в Литві. У середньому в Україні розмір ВВП у розрахунку на одну особу в 5,2 рази нижчий, порівняно з країнами Центральної Європи та Балтики (Болгарія, Польща, Румунія, Словенія, Словаччина, Хорватія, Чехія, Угорщина, Латвія, Литва, Естонія). Незважаючи на те, що місцеві бюджети України співвідносяться з ВВП в тих же пропорціях, що і в країнах $€ C$, їх фрінансові можливості $€$ значно нижчими.

Низький рівень ВВП в Україні становить загрозу економічній та соціальній безпеці країни, поглиблює рівень бідності, зумовлює низькі соціальні стандарти, низьку якість соціальних послуг, і попри щорічне зростання - низькі показники соціальних видатків державного та місцевих бюджетів. Досвід країн ЄС свідчить, що значну частину ВВП створює малий і середній бізнес. Зважаючи на це та враховуючи, що основу доходів місцевих бюджетів України становлять єдиний податок, частка податку на доходи фізичних осіб та частка податку на прибуток підприємств, можна зробити висновки, що надалі розвиток місцевих фрінансів України потребує підтримки та стимулювання розвитку малого і середнього бізнесу.

Реалізація стратегічних рішень потребує здійснення бюджетної політики у сфері видатків, спрямованої на посилення ефективності управління суспільними фрінансами, впровадження комплексу заходів 3 оптимізації видаткових зобов'язань, підвищення ефективності бюджетних видатків. Підвищення ефективності видатків бюджетів у системі державного регулювання $є$ вагомою складовою процесу реформування бюджетного процесу, що вимагає розробки відповідних заходів з оптимізації бюджет- них видатків, підвищення стійкості державного та місцевих бюджетів, фрормування відповідних інститутів, створення сприятливого інституційного середовища [15].

Проведення цілеспрямованої бюджетної політики передбачає запровадження стратегічного бюджетного планування, у процесі якого розширюються можливості щодо ії фрормування за межами річного бюджетного плану, створюються умови для розв'язання найважливіших проблем державного впливу на соціальний розвиток. Науково обґрунтована середньострокова бюджетна політика має відображати вплив попередніх бюджетних зобов'язань, а також майбутні витрати на соціальний розвиток суспільства.

Програмно-цільове бюджетування дає змогу узгодити зі стратегічними планами також і якісні параметри бюджету. В цьому разі ключовими параметрами, за якими відбувається узгодження бюджетної політики зі стратегічним плануванням, $€$ мета витрачання бюджетних коштів, завдання та очікувані результати. В Україні програмноцільовий метод бюджетування передбачає формування документів, які визначають орієнтири для різних горизонтів бюджетного планування. Річні параметри діяльності головних розпорядників коштів визначені у бюджетних програмах. Ширші горизонти бюджетного планування головні розпорядники бюджетних коштів застосовують у формі стратегічних планів міністерств та інших центральних органів виконавчої влади. Саме останній документ виконує головну роль у забезпеченні узгодженості бюджетування головних розпорядників коштів зі стратегічними пріоритетами розвитку країни.

Як зазначають І. Чугунов та В. Макогон, важливо дотримуватися узгодженості бюджетування зі стратегічним плануванням, що дасть змогу підвищити рівень стійкості 
бюджету, ефективність використання бюджетних коштів, збалансування пріоритетів бюджетної політики у стратегічному плані, прогнозованість бюджетних орієнтирів для економічних агентів, підвищити відповідальність головних розпорядників бюджетних коштів за досягнення результатів, визначених у стратегічних планах [15].

В Україні зроблено важливі кроки щодо запровадження середньострокового бюджетного планування, які створюють передумови для узгодження бюджетної політики уряду зі стратегічними пріоритетами, визначеними у програмних документах стратегічного характеру. Зокрема, внесеними на початку 2019 р. змінами до Бюджетного кодексу України на законодавчому рівні передбачено запровадження бюджетної декларації - документа державного стратегічного планування, що визначає засади бюджетної політики на середньостроковий період [16]. Бюджетна декларація має виступати інструментом узгодження основних кількісних бюджетних параметрів із стратегічним плануванням на макрорівні на середньострокову перспективу. Водночас, в останні роки розробку Бюджетної декларації не здійснюють, або не затверджують ії̈ проект, що фрактично спричиняє до так званого “ручного" розподілу бюджетних видатків. Так, у 2016-2018 рр. (до внесених змін до Бюджетного кодексу України) проекти Основних напрямів бюджетної політики Верховною Радою України взагалі не розглядалися. У 2019 р. проект Бюджетної декларації на 2020-2022 рр. Уряд не вніс до Верховної Ради України. Розроблення Бюджетної декларації на 2021-2023 рр. у зв'язку з невизначеністю, спричиненою коронавірусом, призупинено [16]. Як стверджує А. Дешко, відстрочка фактично надає можливість провести додаткову роботу щодо повноцінного впровадження низки бюджетних правил, необхідних для якісного впровадження середньострокового бюджетного планування у 2021 р. [17].

Таким чином, в умовах невизначеності, зумовленої пандемією COVID-19, процеси бюджетування певним чином змінюються, підпорядковуючись короткостроковому плануванню і здійсненню невідкладних антикризових заходів. Бюджетна політика за таких умов спрямована на реалізацію невідкладних антикризових заходів, використовуючи короткострокові/екстрені бюджетні інструменти - додаткові бюджети, створення резервних фондів на випадок непередбачуваних обставин, перерозподіл видатків тощо. Спеціалісти Міжнародного валютного фонду зазначають, що в "умовах високої невизначеності бюджетування під час кризи стає безперервним реактивним процесом...", водночас розробка стратегії, яка в звичайних умовах $є$ важливою складовою процесу підготовки бюджету, в умовах пандемії відіграє ще більшу роль [18]. Це передбачає збереження середньострокової орієнтації бюджетування, окреслення довгострокового впливу заходів з економії бюджетних коштів, визначення бюджетних ризиків, і водночас набагато частіший перегляд базисного бюджетного сценарію, прогнозів, урахування впливу на них зміни макроекономічних показників (ВВП, безробіття, інфляції та ін.), перебігу пандемії.

Зміни середньострокових бюджетних цілей потребують підвищення адаптивності бюджетної політики у сфері видатків, складання гнучких динамічних бюджетів, визначення застережень щодо дотримання бюджетних правил. Зростає роль моніторингу і контролю у процесі виконання державного і місцевих бюджетів за підвищенням ефективності та результативності витрачання бюджетних коштів, створених бюджетних фондів, раціоналізації/оптимізації бюджетних видатків. 
Формування інституту підзвітності влади суспільству сприятиме зміцненню довіри населення до бюджетної і соціальної політики. Це передбачає, крім інших, використання такого інструменту, як огляд видатків/ витрат бюджету. Огляд бюджетних видатків - це процес визначення і порівняння варіантів економії бюджетних коштів, виявлення резервів та їх спрямування в межах соціальних чи інших програм, визначення правильності формулювання цілей тощо. Досвід здійснення оглядів бюджетних видатків/витрат в країнах ОЕСР свідчить, що все більше країн приєднується до цього процесу [19; 20]. Причому здійснюється як операційний огляд (орієнтований на виявлення економії бюджетних коштів переважно без внесення змін у законодавство), так і стратегічний (передбачає внесення змін у законодавство) [19]. Повноцінне його впровадження важливе для оцінки ефрективності видатків бюджету, можливості публічного обговорення оглядів та врахування їх результатів під час формування галузевих стратегій та формування, удосконалення чи коригування бюджетних соціальних програм.

Висновки. Підсумовуючи, зазначимо, що загальні засади удосконалення бюджетної політики на середньо- та довгострокову перспективу на сьогодні полягають у забезпеченні повноцінної інклюзивності економічного розвитку, приведенні функцій держави до суспільно необхідних розмірів та підвищення ефективності бюджетних видатків шляхом належного застосування програмно-цільового методу планування, здійснення обов'язкових щорічних оглядів бюджетних видатків та витрат. У сучасних умовах завдання бюджетної політики передбачає забезпечення ефективності, гнучкості бюджетних видатків, їх спрямування на цілі соціального й економічного розвитку, виходячи із економічної циклічності та макроекономічної ситуації в країні.
Структура видаткової частини бюджету має враховувати макроекономічну динаміку i адаптуватися до сучасних перетворень фрінансової системи та реалізації соціальних пріоритетів, насамперед, стосовно охорони здоров'я та освіти.

Встановлено, що на формування видатків бюджету впливають економічні, політичні, соціальні й інституційні чинники: динаміка ВВП, інфляція, податкова дисципліна, стан дотримання бюджетного законодавства, чіткість планування та застосування його прогресивних форм, трудова активність та рівень доходів населення, якість та дієвість управління, ефективність використання бюджетних коштів, обґрунтованість соціальних стандартів, прозорість бюджетного механізму, досконалість сформованих інститутів.

Підвищенню ефективності видатків державного і місцевих бюджетів має сприяти налагодження дієвого громадського контролю. Залучення громадян до формування бюджету, зокрема внесення пропозицій щодо обґрунтованості фрінансування проектів у форматі бюджету участі, та контролю за цільовим витрачанням бюджетних коштів сприятиме вирішенню двоєдиного завдання - посилення відповідальності органів державної влади та місцевого самоврядування загалом і конкретних виконавців зокрема за реалізацію соціальних бюджетних програм, задоволення потреб громади, відтак покращення якості життя.

Бюджетна політика в сфрері видатків має орієнтуватися на виконання пріоритетних завдань соціального розвитку країни, водночас здійснювати стимулювання ділової й інноваційної діяльності, інвестиційної активності, збереження існуючих та створення нових робочих місць, сприяння розвитку соціальної інфраструктури, що $є$ перспективою подальших досліджень. 


\section{Список використаних джерел}

1. Государственные финансы : учеб. пособие / под ред. В. М. Федосова, С. Я. Огородника, В. Н. Суторминой. Киев : Лыбидь, 1991. 267 с.

2. Опарін В. М. Фінансова система України (теоретико-методологічні аспекти) : монографрія. Київ : КНЕУ, 2005. 239 с.

3. Радіонов Ю. Д. Формування видатків бюджету : монографрія. Київ : КНТЕУ, 2019. 616 с.

4. Набока Т. С. Управління видатками бюджету та напрями його вдосконалення в УкраїHi. Київ : KHEУ, 2015. 345 c.

5. Кириленко О., Малиняк Б. Теоретичні основи формування видаткової частини місцевих бюджетів. Наука й економіка. 2006. № 1. С. 6-16.

6. Бланкарт Шарль. Державні фрінанси в умовах демократії: вступ до фрінансової науки / за наук. ред. В.М. Федосова. Київ : Либідь, 2000. $656 \mathrm{c}$.

7. Статистичний збірник "Бюджет України 2016”. Міністерство фрінансів України. Kuїв, 2017. URL : https://mof.gov.ua/storage/files/ a6d88e3b4e411 ca655003eba01eff826.pdf.

8. Статистичний збірник: "Бюджет України 2019”. Міністерство фрінансів України. URL : https://mof.gov.ua/storage/files/2 Budget of Ukraine_2019_(for_website)\%20(1).pdf

9. Про Стратегію сталого розвитку “Україна - 2020”. Указ Президента України від 12.01.2015 p. № 5/2015. URL : https://zakon.rada. gov.ua/laws/show/5/2015/print.

10. Про цілі сталого розвитку України на період до 2030 року. Указ Президента України від 30 вересня 2019 року № 722. URL : https:// zakon.rada.gov.ua/laws/show/722/2019\#Text.

11. Національна економічна стратегія 2030. Візія. Вектори. Імплементація. Кабінет Міністрів України. 2020. URL : https://nes2030.org.ua/.

12. Липтон Д. Мобилизация фринансирования Повестки дня в области устойчивого развития на период до 2030 года. 2019. URL : https://www.imf.org/ru/News/Articles/2019/09/26/ sp092619-moving-the-money-to-finance-the-2030agenda-for-sustainable-development.
13. Government revenue, expenditure and main aggregates. Eurostat. URL : https://appsso. eurostat.ec.europa.eu/nui/show. do?dataset $=$ gov 10a main\&lang=en.

14. Population change - Demographic balance and crude rates at national level. Eurostat. URL : https://appsso.eurostat.ec.europa.eu/nui/show. do? dataset $=$ demo gind\&lang $=e n$.

15. Чугунов І. Я., Макогон В. Д. Бюджетно-податкова політика в умовах інституційних перетворень. Вісник КНТЕУ. 2014. № 4. C. 79-91.

16. Про внесення змін до Закону України “Про Державний бюджет України на 2020 рік”: Закон України. Відомості Верховної Ради України. 2020. № 19. C. 126. URL : https://zakon.rada. gov.ua/laws/show/553-20\#Text.

17. Дешко А. Л. Напрями формування $i$ реалізації бюджетної політики на середньострокову перспективу. Аналітична записка. HICД. URL : https://niss.gov.ua/sites/default/ files/2020-07/budgetna-polityka.pdf.

18. Вендлинг К., Доэрти Л., Курристин Т., Шейк Рахим Ф., Танг В., Бруно Э. Бюджетирование в условиях кризиса: рекомендации относительно подготовки бюджета на 2021 год. Специальная серия публикаций по мерам налогово-бюджетной политики в ответ на COVID-19. МВФ. 2020. 13 C.

19. Лавров А. М., Ястребова О. К. Новинки бюджетного процесса в странах ОЭСР. Финансовый журнал. 2018. № 2. С. 9-23.

20. Spending reviews: some insights from practitioners / edited by Elva Bova, Riccardo Ercoli and Xavier Vanden Bosch. DISCUSSION PAPER 135. DECEMBER 2020. URL : https://ec.europa.eul info/sites/info/files/dp135_spending_reviews.pdf.

\section{References}

1. Fedosov, V. M., Ogorodnik, S. Ya., Sutormina, V.N. (Ed.). (1991). Gosudarstvennyie finansyi [Public finance]. Kyiv: Lybid [in Russian].

2. Oparin, V. M. (2005). Finansova systema Ukrainy (teoretyko-metodolohichni aspekty) [Finan- 
cial system of Ukraine (theoretical and methodological aspects)]. Kyiv: KNEU [in Ukrainian].

3. Rodionov, Yu. D. (2019). Formuvannia vydatkiv biudzhetu [Formation of budget expenditures]. Kyiv: KNTEU [in Ukrainian].

4. Naboka, T. S. (2015). Upravlinnia vydatkamy biudzhetu ta napriamy yoho vdoskonalennia $v$ Ukraini [Management of budget expenditures and directions of its improvement in Ukraine]. Kyiv: KNEU [in Ukrainian].

5. Kyrylenko, O., Malyniak, B. (2006) Teoretychni osnovy formuvannia vydatkovoi chastyny mistsevykh biudzhetiv [Theoretical foundations of the expenditure part of local budgets]. Nauka i ekonomika - Science and Economics, 1, 6-16 [in Ukrainian].

6. Blankart, Sharl, Fedosov, V.M. (Ed.). (2000). Derzhavni finansy $v$ umovakh demokratii: vstup do finansovoi nauky [Public finances in the conditions of democracy: introduction to financial science]. Kyiv: Lybid [in Ukrainian].

7. Statystychnyi zbirnyk "Biudzhet Ukrainy 2016" [Statistical collection "Budget of Ukraine 2016"]. (2017). Ministerstvo finansiv Ukrainy. Kyiv. Available at: https://mof.gov.ua/storage/files/ a6d88e3b4e411 ca655003eba01eff826.pdf.

8. Statystychnyi zbirnyk: "Biudzhet Ukrainy 2019" [Statistical collection "Budget of Ukraine 2019"]. Ministerstvo finansiv Ukrainy. Available at: https://mof.gov.ua/storage/files/2 Budget of Ukraine 2019. (for website)\%20.pdf.

9. Pro Stratehiiu staloho rozvytku "Ukraina 2020". Ukaz Prezydenta Ukrainy vid 12.01.2015 r. № 5/2015. [About the Sustainable development strategy "Ukraine - 2020". Decree of the President of Ukraine]. (2015, January, 1). Available at: https:// zakon.rada.gov.ua/laws/show/5/2015/print.

10. Pro Tsili staloho rozvytku Ukrainy na period do 2030 roku. Ukaz Prezydenta Ukrainy vid 30 veresnia 2019 roku № 722 [About the Sustainable development goals of Ukraine for the period up to 2030. Decree of the President of Ukraine]. (2019, September, 30). Available at: https://zakon.rada. gov.ua/laws/show/722/2019\#Text.
11. Natsionalna ekonomichna stratehiia 2030 Viziia. Vektory. Implementatsiia Kabinet Ministriv Ukrainy. [National Economic Strategy 2030. Vision. Vectors. Implementation. Cabinet of Ministers of Ukraine]. (2020). Available at: https:// nes2030.org.ual.

12. Lipton, D. (2019). Mobilizatsiya finansirovaniya Povestki dnya $v$ oblasti ustoychivogo razvitiya na period do 2030 goda [Mobilizing funding for the 2030 Agenda for sustainable developmen]. Available at: https://www.imf.org/ru/News/ Articles/2019/09/26/sp092619-moving-the-moneyto-finance-the-2030-agenda-for-sustainable-development.

13. Government revenue, expenditure and main aggregates / Eurostat: ofitsiinyi sait. Available at: https://appsso.eurostat.ec.europa.eu/nui/show. do?dataset $=$ gov $10 \mathrm{a}$ main\&lang=en.

14. Population change - Demographic balance and crude rates at national level. Eurostat: ofitsiinyi sait. Available at: https://appsso.eurostat.ec.europa.eu/nui/show.do?dataset=demo gind\&lang=en.

15. Chuhunov, I. Ya., Makohon, V. D. (2014). Biudzhetno-podatkova polityka $v$ umovakh instytutsiinykh peretvoren [Fiscal policy in terms of institutional transformation]. Visnyk KNTEU - Bulletin of KNTEU, 4, 79-91 [in Ukrainian].

16. Pro vnesennia zmin do Zakonu Ukrainy "Pro Derzhavnyi biudzhet Ukrainy na 2020 rik". Zakon Ukrainy [On Amendments to the Law of Ukraine "On the State Budget of Ukraine for 2020". Law of Ukraine]. (2020). Vidomosti Verkhovnoi Rady Ukrainy - Information of the Verkhovna Rada of Ukraine, 19, 126. Available at: https://zakon. rada.gov.ua/laws/show/553-20\#Text.

17. Deshko, A.L. (2020). Napriamy formuvannia i realizatsii biudzhetnoi polityky na serednostrokovu perspektyvu. Analitychna dopovid [Directions of formation and implementation of budget policy for the medium term]. NISD. Available at: https:/l niss.gov.ua/sites/default/files/2020-07/budgetnapolityka.pdf. 


\section{АКТУАЛЬНІ ПИТАННЯ ТЕОРІЇ І ПРАКТИКИ ФІНАНСІВ}

18. Vendling, K., Doerti, L., Kurristin, T., Sheyk Rakhim, F., Tang, V., Bruno, E. (2020). Byudzhetirovanie $v$ usloviyakh krizisa: rekomendatsii otnositelno podgotovki byudzheta na 2021 god [Budgeting in a crisis: recommendations for the preparation of the budget for 2021]. Spetsialnaya seriya publikatsiy po meram nalogovo-byudzhetnoy politiki v otvet na COVID-19 - A special series of publications on fiscal policy measures in response to COVID-19. MVF.
19. Lavrov, A. M., Yastrebova, O. K. (2018). Novinki byudzhetnogo protsessa $v$ stranah OESR [New items of the budgetary process in the OECD countries]. Finansovyiy zhurnal - Financial Journal, 2, 9-23 [in Russian].

20. Elva, Bova, Riccardo, Ercoli and Xavier, Vanden Bosch (Ed.). Spending reviews: some insights from practitioners. DISCUSSION PAPER 135. DECEMBER 2020. Available at: https:// ec.europa.eu/info/sites/info/files/dp135 spending reviews.pdf.

Стаття надійшла до редакції 18.09.2020. 